\title{
Yeshi Dhonden: personal physician to the 14th Dalai Lama
}

This article (BMJ 2020;368:m201, doi:10.1136/bmj.m201)

contained spelling errors which have now been corrected. 